\title{
A study of serum magnesium level in type 2 diabetes mellitus and its significance
}

\author{
Prabhu G', Raadha $\mathrm{AM}^{2}$, Balasubramaniyan $\mathrm{S}^{3}$ \\ ${ }^{1}$ Dr Prabhu G, Assistant professor, ${ }^{2}$ Dr Radha AM, Post Graduate student, ${ }^{3}$ Dr Balasubramaniyan S, Professor and Head \\ of department. All are affiliated with department of General medicine, Rajah Muthiah Medical College, Chidambaram, \\ India
}

Address for correspondence: Dr Prabhu G, Email: kggprabhu@gmail.com

\begin{abstract}
Introduction: Hypomagnesaemia has been reported to occur in $25-38 \%$ of patients with Type 2 DM especially in those without good metabolic control. This present study has been undertaken to estimate serum magnesium level of patients with diabetes mellitus and to correlate between serum magnesium levels and glycemic control, duration of diabetes and its complications. Methods and Materials: This is a prospective study done in March 2015 in Rajah Muthiah Medical College and Hospital. 132 Type 2 DM patients included in the study was estimated with serum magnesium level and compared with the age matched control group. Results: The mean serum magnesium was $1.74 \pm 0.32 \mathrm{mg} / \mathrm{dl}$. Of the patients, $33(25 \%$ ) had low serum magnesium levels (less than or equal to $1.5 \mathrm{mg} / \mathrm{dl}$ ). We observed that serum magnesium levels were lower in patients with increasing duration of diabetes. Out of the 19 patients who had hypomagnesaemia, 18 patients had HbA1c > $7 \%$. This correlates between hypomagnesaemia and poor glycemic control in our study. Conclusion: Serum magnesium level was low in Type 2 DM; serum magnesium was low in patient with poor glycemic control.
\end{abstract}

Keywords: Type 2 Diabetes Mellitus, Glycemic Control, Serum Magnesium

\section{Introduction}

Diabetes is an iceberg disease. The prevalence of diabetes in adults was around $4 \%$ worldwide. The recent WHO report suggests that over $19 \%$ of worlds diabetic population currently resides in India [1]. Magnesium is the fourth most abundant mineral in the body and the most abundant intracellular divalent cation, with essential roles in many physiological functions [2]. Hypomagnesaemia is known to occur in diabetes. Hypomagnesaemia has been reported to occur in $25-38 \%$ of patients with type $2 \mathrm{DM}$ especially in those without good metabolic control [3].

Magnesium modulates glucose transport through the membrane and it is a cofactor in several enzymatic reactions involving glucose oxidation. Its deficiency may increase insulin résistance. The reasons for magnesium deficiency in diabetes are not very clear. This could be due to higher urinary loss and lower dietary intake/impaired absorption [4].This present

Manuscript received: $20^{\text {th }}$ June 2015

Reviewed: $5^{\text {th }}$ July 2015

Author Corrected: $14^{\text {th }}$ July 2015

Accepted for Publication: $26^{\text {th }}$ July 2015 study has been undertaken to estimate serum magnesium level of patients with diabetes mellitus attending our outpatient department and to correlate between serum magnesium levels and glycemic control, duration of diabetes and its complications.

\section{Materials and Methods}

This study was a prospective study done over a period of one month from March $1^{\text {st }}$ to march $31^{\text {st }} 2015.132$ patients of Type 2 DM getting treatment from Rajah Muthiah Medical College and Hospital were included in this study. Inclusion criteria Type 2 diabetes mellitus, age 18 and above were included. Exclusion criteria Type 1 diabetes mellitus, alcoholism, chronic diarrhea, patients on diuretics and malabsorption syndrome. Detailed history from the subjects and examination was done to diagnosis of micro vascular and macro vascular complication of diabetes. Laboratory values were also supported. Serum magnesium levels were estimated in the study group, 30 age matched healthy controls were compared. Normal serum magnesium level is $1.5-2.5$ $\mathrm{mg} / \mathrm{dl}$. Less than $1.5 \mathrm{mg} / \mathrm{dl}$ is considered as 
hypomagnesaemia. Element specific electrode ionic method was used to estimate serum magnesium levels.

\section{Results}

132 patients with Type $2 \mathrm{DM}$ who were treated in $\mathrm{RMMCH}$ in the month march 2015 were included in the study. Among the study group youngest patient was 26 years and the oldest patient was 85 years. Majority of the patients (81/132) were between 40-60 years. Of 132 patients, 71(53.79\%) were females and 61(46.21\%) were males. The mean BMI was $25 \pm 8.7$.

Total132 patients were studied and divided into three groups according to duration of Type 2 DM namely: group I (less than 5 years), group II (5 to 9 years) and group III (10 \& more than 10 years). 72 patients (54.54\%) were in group I and 30 of these were newly diagnosed.22(15.90\%) were in group II.39(29.54\%) were in group III and out of this 9 had DM for more than 20 years.

\section{Glycemic status of the study group:}

Figure 1: shows the HbAlc of the patients studied.

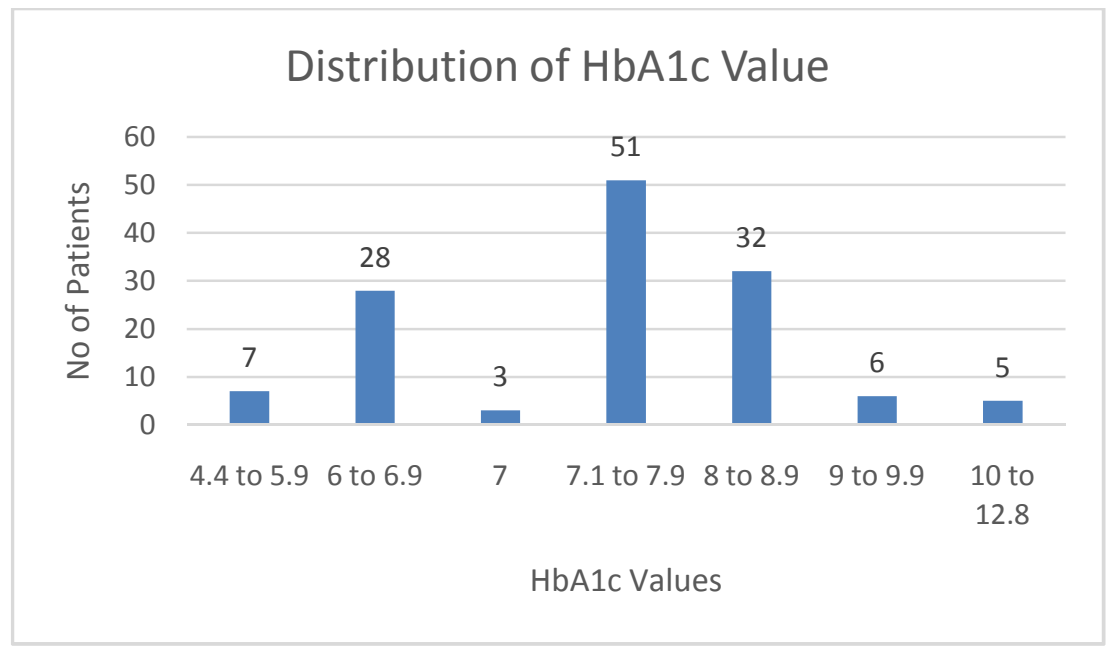

The range of HbA1c was 4.4 to $12.8 \%$. HbA1c of $7 \%$ and less considered as good glycemic control, above $7 \%$ considered as poor glycemic control. The mean $\mathrm{HbA} 1 \mathrm{c}$ was $7.63 \% \pm 2.5 \%$. The HbA1c value was more than $7 \%$ in 94/132 (71.2\%) patients and 7\% \& less than 7\% in 38/132(28.78\%) patients. There were five patients with HbA1c level $>10 \%$ indicating very poor glycemic control.

\section{Serum Magnesium Levels:}

Figure 2: Serum Magnesium Levels in Study group

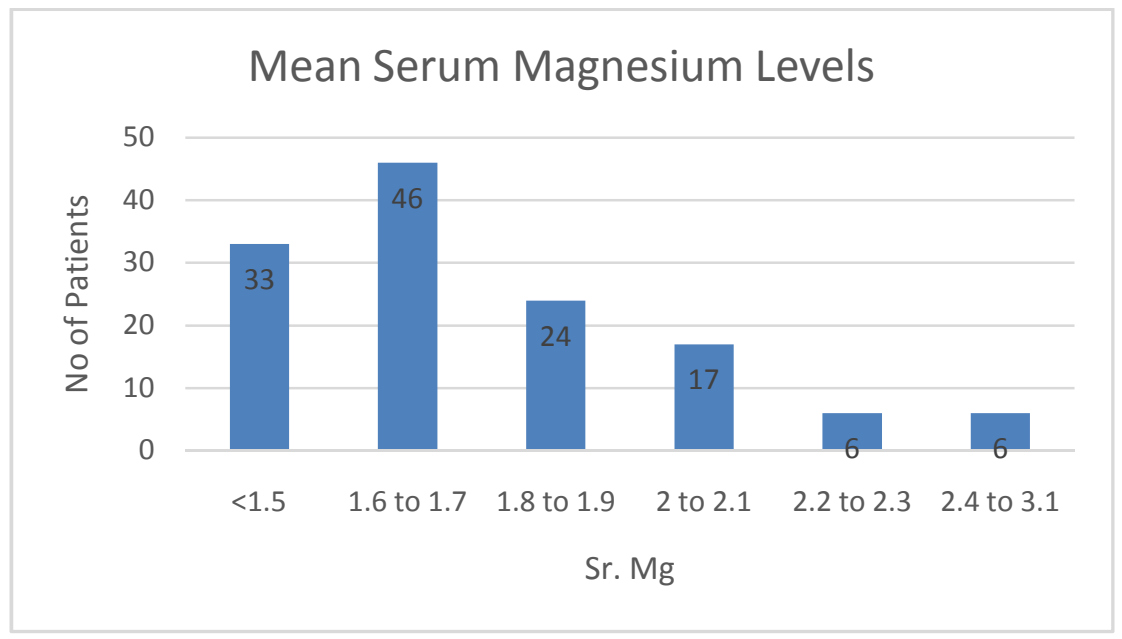


In present study the serum magnesium levels varied between 1.1 to $3.1 \mathrm{mg} / \mathrm{dl}$. Our normal laboratory value for magnesium is $1.5-2.5 \mathrm{mg} / \mathrm{dl}$. The mean serum magnesium was $1.74 \underline{ \pm} 0.32 \mathrm{mg} / \mathrm{dl}$. Of the patients, $33(25 \%)$ had low serum magnesium levels(less than or equal to $1.5 \mathrm{mg} / \mathrm{dl}$ ). The serum magnesium levels in 30 healthy controls.

Thirty healthy patients were selected randomly. These included RMMCH staff members and subjects coming for master health check up and routine out patients. The serum magnesium levels in the control group ranges between 1.6 to 2.1 $\mathrm{mg} / \mathrm{dl}$. The mean serum magnesium in this group was $1.84 \pm 0.142 \mathrm{mg} / \mathrm{dl}$.

\section{Serum magnesium in relation to duration of diabetes:}

Table 1: serum magnesium level in relation to duration of diabetes

\begin{tabular}{|l|l|l|l|}
\hline Duration of diabetes & No. of patients & Mean HbA1C & Mean serum magnesium \\
\hline$<5$ years & 72 & 7.54 & 1.8 \\
\hline $5-9$ years & 21 & 7.68 & 1.73 \\
\hline$>10$ years & 39 & 7.86 & 1.63 \\
\hline
\end{tabular}

Table 1 shows the mean serum magnesium level in relation to duration and glycated hemoglobin. We observed that patients with longer duration of diabetes had higher mean HbA1c values and lower mean serum magnesium values.

Table 1(a): serum magnesium level in three groups, Duration of diabetes - <5 years, 5-9years, $>10$ years

\begin{tabular}{|l|l|l|l|l|}
\hline $\begin{array}{l}\text { Serum magnesium } \\
\text { levels }\end{array}$ & $\begin{array}{l}\text { Number of } \\
\text { patients }\end{array}$ & $\mathbf{< 5}$ years & $\mathbf{5 - 9}$ years & $>\mathbf{1 0}$ years \\
\hline$<1.5$ & 19 & 12 & 01 & 06 \\
\hline $1.5-1.7$ & 60 & 33 & 08 & 19 \\
\hline $1.8-2.0$ & 34 & 18 & 05 & 11 \\
\hline $2.1 \&$ above & 19 & 11 & 05 & 03 \\
\hline
\end{tabular}

Table 1 (a) shows the distribution of magnesium levels in relation to the duration of diabetes. We observed that a total of 19 patients had serum magnesium of less than $1.5 \mathrm{mg} / \mathrm{dl}, 60$ patients had a serum magnesium level between 1.5 $1.7 \mathrm{mg} / \mathrm{dl}$.

Table 2: distribution of hypomagnesaemia in three groups

\begin{tabular}{|l|l|l|l|}
\hline Duration of diabetes & Normal Sr.Mg & Low Sr.Mg & Total \\
\hline$<5$ years & 56 & 16 & 72 \\
\hline $5-9$ years & 14 & 7 & 21 \\
\hline$>10$ years & 29 & 10 & 39 \\
\hline Total & 99 & 33 & 132 \\
\hline
\end{tabular}

Sixteen of 132 patients with diabetes mellitus for less than 5 years had low serum magnesium. Ten out of 39 patients with diabetes mellitus $>10$ years duration had low serum magnesium. However, on statistical analysis it was found that there was no significant correlation between duration of diabetes and serum magnesium levels $\left(\chi^{2}=0.06, p=0.803\right)$

Table 3: Mean serum magnesium vs. HbA1c

\begin{tabular}{|l|l|l|}
\hline HbA1c $(\mathbf{N}=\mathbf{1 3 2})$ & $\mathbf{4 . 4} \mathbf{- 7}$ \% ( N=38) & $\mathbf{7 . 1} \mathbf{- 1 2 . 8 \%}(\mathbf{N = 9 4})$ \\
\hline Mean Sr.Mg (mg/dl) & 1.852 & 1.696 \\
\hline
\end{tabular}

Table 3 shows that mean serum magnesium value in patients with HbA1c less than or equal to $7 \%$ and patients with $\mathrm{HbA1c}$ more than $7 \%$. Mean serum magnesium level was high in groups with $\mathrm{HbA1c}<7 \%$ 
Table 4: distribution of serum magnesium level in relation to HbAlc

\begin{tabular}{|l|l|l|l|l|l|l|}
\hline $\begin{array}{l}\text { Serum } \\
\text { magnesium levels }\end{array}$ & $\begin{array}{l}\text { Number of } \\
\text { patients }\end{array}$ & $\begin{array}{l}\text { HbA1c } \\
<\mathbf{5 \%}\end{array}$ & $\begin{array}{l}\text { HbA1c } \\
\mathbf{5 - 7 \%}\end{array}$ & $\begin{array}{l}\text { HbA1c } \\
\mathbf{7 . 1} \mathbf{- 8 \%}\end{array}$ & $\begin{array}{l}\text { HbA1c } \\
\mathbf{8 . 1} \mathbf{- 9 \%}\end{array}$ & $\begin{array}{l}\text { HbA1c } \\
>\mathbf{9 \%}\end{array}$ \\
\hline$<1.5$ & 19 & 0 & 1 & 9 & 8 & 1 \\
\hline $1.5-1.7$ & 60 & 1 & 18 & 33 & 7 & 1 \\
\hline $1.8-2.0$ & 34 & 0 & 10 & 14 & 6 & 4 \\
\hline $2.1 \&$ above & 19 & 0 & 8 & 2 & 6 & 3 \\
\hline
\end{tabular}

Table 4 shows the number of patients with low serum magnesium levels in both controlled and uncontrolled diabetics as indicated by HbA1c levels. There were 19 patients with low magnesium level $(<1.5 \mathrm{mg} / \mathrm{dl})$ out of which 18 patients had HbA1c value $>7 \%$ whereas only 1 patient had low serum $\mathrm{Mg}$ level in group with $\mathrm{HbA} 1 \mathrm{c}<7 \%$. This difference was found to be statistically significant $(\mathrm{p}=0.0007)$.

Table 5: distribution of complications

\begin{tabular}{|l|l|l|l|}
\hline Complications & Low Mg & Normal Mg & Total (\%) \\
\hline Neuropathy & 21 & 14 & $35(26.51 \%)$ \\
\hline Nephropathy & 14 & 12 & $26(19.69 \%)$ \\
\hline Retinopathy & 11 & 11 & $22(16.66 \%)$ \\
\hline CVA & 3 & 4 & $7(5.03 \%)$ \\
\hline CAD & 14 & 9 & $23(17.24 \%)$ \\
\hline PVD & 3 & 0 & $3(2.27 \%)$ \\
\hline
\end{tabular}

Total 76 patients in the study group had one or more macro or micro vascular complications. Of this, 48 patients had single complications, 19 patients had two complications, 6 patients had three complications and 3 had four complications. There were more patients with micro vascular complications. 35 patients had neuropathy, 26 had nephropathy and 22 had retinopathy. Among macro vascular complications coronary artery disease was the commonest. The correlation was analyzed separately by Pearson method, $\mathrm{P}=0.105$ (not significant)

Table 6: mean serum magnesium levels in patients with complications

\begin{tabular}{|l|l|l|l|l|l|l|}
\hline Complications & Neuropathy & Nephropathy & Retinopathy & CVA & CAD & PVD \\
\hline mean Sr.Mg & 1.705 & 1.661 & 1.704 & 1.707 & 1.914 & 1.7 \\
\hline
\end{tabular}

Table 6 shows the lowest mean serum $\mathrm{Mg}$ was found in patients with nephropathy. Other complications like neuropathy, retinopathy, CAD, PVD were having mean serum magnesium around $1.7 \mathrm{mg} / \mathrm{dl}$

Table 7: Hypomagnesaemia vs. diabetic complications

\begin{tabular}{|l|l|l|l|}
\hline Patients $\mathbf{( N ~ = 1 3 2 )}$ & Low magnesium & Normal magnesium & Total \\
\hline With complications & 20 & 56 & 76 \\
\hline Without complications & 13 & 43 & 56 \\
\hline Total & 33 & 99 & 132 \\
\hline
\end{tabular}

Among 132 patients, 76 patients had diabetic complications. Of this, 20 patients had low magnesium levels. Of the 56 patients without complications 13 had low serum magnesium levels. This difference was analyzed statistically and there was no significant correlation $(\chi 2=0.6488, \mathrm{p}=0.42)$

\section{Discussion}

This study was a case control study for a period of one month in March 2015. 132 Type 2 DM were selected randomly and were included in the study. In the present study, 94 of 132 patients $(71.21 \%)$ had uncontrolled hyperglycemia with $\mathrm{HbA} 1 \mathrm{c}$ more than $7 \%$ as defined in
ADA statements.48 patients $(52.75 \%)$ had complications. While comparing the glycemic status with duration of diabetes, the highest mean HbA1c was found in group III (>10 years of diabetes). Type 2 DM is a progressive disorder. There is progressive deterioration of glycemic control with increasing 
duration of the disease due to progressive beta cell failure and it accounts for the inadequacy of the treatment. In a study done by Reheja et al [5] it was found that Indians had the highest HbA1c values among Asian patients with diabetes. They also found that the mean $\mathrm{HbA1c}$ value was increasing with duration of diabetes.

Serum magnesium level in patients: In the present study, 33 patients $(25.00 \%)$ had low serum magnesium levels $\leq 1.5 \mathrm{mg} / \mathrm{dl}$. Similarly A.G.Kulkarni et al in his study concluded that low magnesium is common in Type 2 DM [6]. Mohamed Murtuza Kauser et al in his study concluded serum magnesium level was lower in Type 2 DM [7]. However the free level of magnesium cannot be estimated by serum magnesium level alone. Only $1 \%$ of body's magnesium stores are distributed in the extra cellular fluid. Serum magnesium is not a good indicator to reflect body's magnesium depletion. Maria de Lourdes et al [3] studied the effect of magnesium supplementation in increasing dose on the control Type 2 DM. In the study $47.7 \%(\mathrm{~N}=128)$ had low plasma magnesium and $31.1 \%$ had low intra mononuclear $\mathrm{Mg}$ levels. They concluded that there was no correlation between intracellular and serum magnesium levels. However they found better control of diabetes with increasing dose of magnesium supplementation in diabetics. Similarly Maj et al [8] in their study in 1995 found that the serum magnesium levels were significantly lower in participants with cardiovascular disease, hypertension and diabetes than in those free of these diseases. Paolisso et al [9] 1989 suggested that magnesium supplementation was found to improve insulin sensitivity and metabolic control in Type 2 DM with decreased serum magnesium level.

Magnesium and diabetes: Insulin has been proposed as a regulatory hormone of magnesium balance; indeed, following ingestion of glucose load, insulin causes a shift of magnesium from extracellular into intracellular space, thus producing a significant decline in plasma magnesium with an accompanying increase in erythrocyte magnesium content. Opposite changes in plasma and erythrocyte magnesium levels are also seen during a euglycemic - hyperinsulinaemic glucose clamp. In diabetic patients, plasma magnesium is inversely related to metabolic control [10].

At the cellular level, patients with diabetes, as compared with non diabetic subjects, displayed suppressed cytosolic free magnesium and increased free calcium. Monika $\mathrm{K}$ Walti et al studied magnesium absorption and retention in type 2 diabetes and they found that they are not impaired in patients with reasonably well controlled type 2 diabetes mellitus [4]. In a study from Kashmir, India by AH Zagar, NA Shah et al [11] reported the levels of copper, zinc and magnesium in non dependent diabetes mellitus. Plasma copper, zinc, magnesium levels were compared with diabetic and non-diabetic subjects. They observed that age, sex, duration and control of diabetes did not influence the serum copper, zinc and magnesium concentrations.

Serum magnesium level and duration of diabetes: We observed that serum magnesium levels were lower in patients with increasing duration of diabetes. In the present study we were not able to find any significance between the serum magnesium levels with relation to the duration of diabetes.

Serum magnesium level and glycemic control: Out of the 19 patients who had hypomagnesaemia, 18 patients had HbA1c > $7 \%$. This correlation between hypomagnesaemia and poor glycemic control was statically significant $(\mathrm{P}=0.007)$. Similarly S.Ramadass et al in his study found serum magnesium levels were found to decline with rise in HbA1c levels and duration of Type 2 DM [12]. Sharma A et al in his study concluded poor glycemic control was associated with hypomagnesaemia [13]. In a study from Zurich, Switzerland, Walti MK et al [14] found that hypomagnesaemia was common in Type $2 \mathrm{DM}$ but did not have any significant correlation with HbA1c.

Hypomagnesaemia and diabetic complication: In the present study 76 patients $(57.57 \%)$ were found to have a combination of diabetic micro and macro vascular complications. Of this, 48 patients had single complication, 19 patients had two complications, 6 patients had three complications and 3 patients had four complications. Micro vascular complications were found to be present in more number of patients. Among the macro vascular complications coronary artery diseases was the commonest. The Chennai urban population study (CUPS-16) by Mohan V Shanthirini CS et al [15] showed that mortality rates due to diabetes in urban population was mainly due to cardiovascular and renal diseases.

As said earlier, hypomagnesaemia is well known to occur in diabetes especially those with poor glycemic control. A study by Martha Rodriguez Moran and Fernando from Mexico has shown that serum 
magnesium depletion is observed and shows a strong relationship with foot ulcers in subjects with Type 2 DM [16].

Hypomagnesaemia can potentiate chronic diabetic complications probably as a result of its positive action in inositol transport (through ATPase activation)[8 ] or its action of reducing platelet aggregation . Nadler et al pointed out that hypomagnesaemia may double the risk of developing coronary artery disease in a diabetic patient because of increasing platelet reactivity [17].

Guerrero -Romero $F$ et al suggested that hypomagnesaemia by a etiopathogenic pathway independent of glycemic status may be involved in the reduction of HDL -cholesterol [18]. Lipinski B, Lipinski $\mathrm{L}$ et al studied the effect of magnesium on fibrin formation from low molecular weight fibrinogen and they found that the circulating fibrinogen in human blood is comprised of high molecular weight (HMW) and lower molecular weight fractions (LMW). LMW fraction of fibrinogen was significantly increased in diabetic patients [19].

\section{Conclusion}

As the study states a significant decrease in the serum magnesium levels in patients with Type $2 \mathrm{DM}$, in poor glycemic status and with multiple micro-macro vascular complications, it is important to insist magnesium supplementation on uncontrolled Type 2 diabetes.

\section{Limitations}

As the growing problem of Type 2 DM and its complication it's important to understand the concepts in it. The study population is limited it require a more study population and elaborate study with estimation of other trace elements in Type 2 DM.

\section{Funding: Nil}

\section{Conflict of interest: Nil}

Permission from IRB: Yes

\section{References}

1. Park k. Diabetes mellitus parks preventive and social medicine 17 edition. M/S banarsidas bhanot publishers; 2002: p294-296.

2. Arnaud MJ . Update on the assessment of magnesium status. Br J Nutr. 2008 Jun; 99 Suppl 3:S24-36. doi: $10.1017 /$ S000711450800682X.
3. de Lordes Lima M, Cruz T, Pousada JC, Rodrigues LE, Barbosa K, Canguçu V. The effect of magnesium supplementation in increasing doses on the control of Type 2 DM. Diabetes Care. 1998 May; 21(5):682-6.

4. Wälti MK, Zimmermann MB, Walczyk T, Spinas GA, Hurrell RF. Measurement of magnesium absorption and retention in type $2 \mathrm{DM}$ with use of stable isotopes. Am J Clin Nutr. 2003 Sep; 78(3):44853.

5. Raheja BS, Kapur A, Bhoraskar A, Sathe SR, Jorgensen LN, Moorthi SR, Pendsey S, Sahay BK. Diabetes care Asia - India study: Diabetes care in India current status J Assoc Physicians India. 2001 Jul; 49:717-22.

6. A.G.Kulkarni ,Sachin K. Shendge, Vikramaditya shinde, Study of serum magnesium level in Type 2 Diabetes Mellitus , IOSR Journal of Dental and Medical Sciences (IOSR-JDMS) e-ISSN: 2279-0853, p-ISSN: 2279-0861.Volume 13, Issue 4 Ver. VII. (Apr. 2014), PP 115-119

7. Mohamed Murtuza Kauser, Asfia Afreen , Prabhakar K, Vageesh Kumar S R and Dinesh Javarappa, Study of serum magnesium in type 2 Diabetes Mellitus and its correlation with the modality of treatment- A south Indian study, International Journal of Biomedical And Advance Research, SSN: 2229-3809 (Online) Journal DOI:10.7439/ijbar

8. Maj, Folsom AR, Melnick SL, Eckfeldt JH, Sharrett AR, Nabulsi AA, Hutchinson RG, Metcalf PA. Serum magnesium and dietary magnesium associated with cardiovascular disease, hypertension, diabetes, insulin and carotid arterial wall thickness; the ARJC study. J Clin Epidemiol. 1995 Jul; 48(7):927-40.

9. Paolisso $\mathrm{G}^{1}$, Sgambato S, Pizza G, Passariello $\mathrm{N}$, Varricchio $\mathrm{M}$, D'Onofrio $\mathrm{F}$. Improved insulin response and action by chronic magnesium administration in aged NIIDM subjects. Diabetes Care. 1989 Apr; 12(4):265-9.

10. Djurhuus MS. New data of mechanisms of hypermagnesuria in type 1 diabetes mellitus. Magnes Res. 2001 Sep; 14(3):217-23.

11. AH Zagar, NA Shah, SR Masoodi, BA Laway et al. Copper, Zinc, and magnesium levels in non-insulin 
dependent diabetes mellitus. Post graduate medical journal 1998; 74: 665-668

12. S.Ramadas, sharbari basu, A.R.Srinivasan, serum magnesium levels as an indicator of status of diabetes mellitus type 2, Diabetes and metabolic syndrome: clinical research and reviews; volume 9, issue 1 January-march 2015 page 42-45

13.Sharma A, Dabla S, Agrawal RP, Barjatya H, Kochar DK, Kothari RP, serum magnesium: an early predictor of course and complications of diabetes mellitus: J Indian med assoc 2007 jan:105(1): 16,18,20

14. Walti MK, Zimmermann MB, Spinas GA, Hurrell RF. Low plasma magnesium in Type 2 diabetes. Swiss Med Wkly. 2003 May 17; 133(19-20):289-92.

15. Mohan V, Shanthirini CS, Deepa M. Chennai urban population study-16. Diabesis Res Clin pract.1998 Sep; 34(1): $29-36$
16. Martha Rodriguez-Moran, Fernando GuerreroRomero. Low serum magnesium levels and foot ulcers in subjects with type 2 diabetes. Arch Med Res. 2001 Jul - Aug; 32(4): 300-3

17. Nadler JL, Malayan S, Luong H, Shaw S, Natarajan RD, Rude RK. Intracellular free magnesium deficiency plays a key role in decreased reactivity in type 2 diabetes mellitus. Diabetes Care. 1992 Jul; 15(7):83541.

18. Guerrero-Romero F, Rodríguez-Morán M. low serum magnesium levels and metabolic syndrome. Acta Diabetol. 2002 Dec; 39(4):209-13.

19. Lipinski B, Lipinska L. Effect of magnesium on fibrin formation from lower molecular weight (LMV) fibrinogen. Magnes Res. 2000 Dec; 13(4):233-7.

\section{How to cite this article?}

Prabhu G, Raadha AM, Balasubramaniyan S. A study of serum magnesium level in type 2 diabetes mellitus and its significance. Int J Med Res Rev 2015;3(7):675-681. doi: 10.17511/ijmrr.2015.i7.125. 